\title{
Induced chlorophyll mutations in Delphinium malabaricum (Huth) Munz.
}

\author{
Firdose Kolar ${ }^{1}$, Nilesh Pawar² and Ghansham Dixit* \\ ${ }^{1}$ Laboratory of Cytogenetics and Plant Breeding, Department of Botany, Shivaji University, Kolhapur - 416004. \\ ${ }^{2}$ Present address: Department of Botany,The New College, Kolhapur-416 012 (MS), India. *E-mail: g_b_dixit@yahoo.co.in
}

\begin{abstract}
The phenotypic response of Delphinium malabaricum to chemical mutagens (EMS and SA) and physical mutagen (gamma rays) were studied. It was observed that $D$. malabaricum manifested specific reactions to the treatments with EMS, SA and gamma rays. Different mutation frequencies and width of mutation spectra were induced under the action of different concentrations of the applied mutagens. Eleven different types of chlorophyll mutants namely albina, albina-green, xantha, aurea, chlorina, viridis, yellow viridis, tigrina, striata, maculata and variegated type were identified in the treated populations and chlorophyll mutation frequency was calculated on plant population basis. Frequency of viridis mutants were highest followed by xantha and other types in all the treatments. The treatments of EMS were found to be more efficient than SA and gamma rays in inducing chlorophyll mutations. The highest frequency of chlorophyll mutations (9.74\%) was reported in the $0.25 \%$ EMS. Quantitative estimation of chlorophyll pigments was also done in different kinds of chlorophyll mutants and chlorophyll content was found in the following decreasing order: chlorina > maculata> variegated $>$ striata $>$ tigrina $>$ viridis $>$ yellow viridis $>$ albina green $>$ aurea $>$ xantha $>$ albina. The study of induced genetic variability for frequency and spectrum of chlorophyll mutations is the first report in D. malabaricum.
\end{abstract}

Key words: D. malabaricum, mutagens: EMS, SA, gamma rays, chlorophyll mutants

\section{Introduction}

Gene mutations influencing the green coloration of photosynthetically active parts are among the most common spontaneous or induced alterations arising in higher plants. The chlorophyll mutation frequency is an indicator to predict the frequency of factor mutations and thus an index for evaluation of genetic effects of mutagens (Gustafsson, 1951; D'Amato et al., 1962; Gichner and Veleminsky, 1965 and Walles, 1973). Nuclear gene mutations or extra chromosomal mutations might result in chlorophyll deficient mutations (Levine, 1972; Walles, 1973 and Wildman, 1973).

Chlorophyll mutations are considered as the most dependable indices for evaluating the efficiency of different mutagens in inducing the genetic variability for crop improvement and are also used as genetic markers in basic and applied research. The occurrence of chlorophyll mutations after treatments with physical and chemical mutagens have been reported in several crops (Swaminathan et al., 1962; Prasad and Das,1980; Sharma and Sharma, 1981; Reddy and Gupta, 1989; Kharkwal,1998; Mitra and Bhowmik, 1999 and Solanki, 2005).

The genus Delphinium of the family Ranunculaceae is an important genetic resource for cut flower cultivars and consists of about 370 species distributed in North temperate regions of the world (Blanché, 1991) and is represented by about 24 species in India mainly confined to Himalayan regions (Rau, 1993). One of its species, D. malabaricum (Huth) Munz., is a vulnerable and endemic perennial herb found on the hilly ranges of North Western Ghats of Maharashtra. It is the only species of the genus found in Western Ghats (Pai et al., 2007). This plant has great ornamental value because of its beautiful and attractive flowers of violet blue colour. As novelty and uniqueness are two of the highly cherished objectives in ornamental plant improvement, mutagenesis is an extremely useful technique in creating new genetic variability and in augmenting existing one. Induced mutation has been reported to be an efficient technique to achieve the desirable characters in flowers and ornamental plants which produced many plants with improved economic value (Broertjes and van Harten, 1988; Anon, 1995). Besides the economic benefits, some mutants also play an important role in the study of genetics and plant development (Van den Bulk et al., 1990; Bretagne-Sagnard et al., 1996). The production of chlorophyll-deficient mutants is a common phenomenon in mutagenesis experiments and it has been reported in monocots (Khalatkar and Bhargava, 1982) and dicots (Miller et al., 1984; Aviv and Galum, 1985; and Alcantara et al., 1996). These mutants usually have not been the subject of interest, but leaf variegation is an important factor influencing the popularity of ornamental plants.

Genetic variability has been induced through mutagenesis in several ornamental plants, but the information available in $D$. malabaricum is meager, so induced mutations were undertaken to bring-forth genetic improvement of this plant. In the present study attempt has been made to understand the comparative response of physical and chemical mutagens on D. malabaricum, with a view to determine the mutagen and treatment causing maximum chlorophyll mutations in $\mathrm{M}_{1}$ generation.

\section{Materials and methods}

Dry and uniform seeds (300) of D. malabaricum, collected from the locality Ajinkyatara at Satara district of Maharashtra, India, were used for inducing mutation by Gamma rays, Ethyl methanesulfonate (EMS) and Sodium Azide (SA). 
Gamma rays treatment: Dry and healthy seeds of $D$. malabaricum were irradiated from a ${ }^{60} \mathrm{CO}$ source at Bombay Atomic Research Centre (BARC), Mumbai with a dose of 5, 10, 15, 20 and 25kR. Untreated seeds were used as control.

EMS and SA treatment: For chemical mutagen treatment, seeds were pre-soaked for 12 hours in distilled water, blotted dry, and treated with freshly prepared aqueous solution of ethyl methane sulphonate (EMS) and sodium azide (SA) at different concentrations $(0.01,0.05,0.10,0.15,0.20,0.25$, and $0.30 \%$ ) for six hours at room temperature $\left(23 \pm 2^{\circ} \mathrm{C}\right)$ with intermittent shaking. After the treatment, the seeds were washed thoroughly with distilled water for eight to ten times to leach out residual chemicals. Both physical gamma rays irradiated and chemically treated (EMS \& SA) seeds along with control (untreated seeds) were sown in the field to raise $M_{1}$ generation.

The $\mathrm{M}_{1}$ population was screened for frequency and spectrum of chlorophyll mutations. Lethal chlorophyll mutations were scored within 10 to 25 days after sowing, whereas viable chlorophyll mutations were scored throughout the life period of plants. The spectrum of chlorophyll mutations was studied and the mutants were classified as per the scheme of Gustafson (1940) and Blixt (1972).

Chlorophyll content and chlorophyll a/b ratio: Chlorophyll content was determined in each type of chlorophyll mutant. Pigments were extracted from the fresh leaf tissues with $80 \%$ acetone ( $1 \mathrm{~mL} / 10 \mathrm{mg}$ of tissue) and the extract was centrifuged at $5000 \mathrm{rpm}$ for $5 \mathrm{~min}$ (to sediment chlorophyll-free particulate material) and the absorbance of the supernatant solution was determined at 663 and $645 \mathrm{~nm}$. Total chlorophyll contents and chlorophyll $a / b$ ratios were calculated by using the equations of Arnon (1949).

\section{Results}

Frequency and spectrum of chlorophyll mutants: In the present investigation, eleven different types of chlorophyll mutants were recorded in $M_{1}$ generation for the different doses/ concentrations of EMS, SA and gamma rays. They were albina, albina-green, xantha, aurea, chlorina, viridis, yellow viridis, tigrina, striata, maculata and variegated type. Albina (Fig.1b) mutants were completely devoid of chlorophyll and could survive only a few days. Albina green and yellow viridis (Fig. 1c and h) had green white and yellow green leaves, respectively, are lethal mutations. Aurea (Fig.1e) had golden yellow coloured leaves and xantha (Fig. 1d) had pale yellow coloured seedlings, these mutants could not survive more than a few days due to block in chlorophyll synthesis (Blixt, 1961). Several other types of chlorophyll deficient mutants such as tigrina, striata, maculata (Fig. 2i, j and k) survived for 40 to 50 days whereas chlorina, viridis, (Fig. 1f and g) and variegated types (Fig. 2l) survived till maturity. Significant variation in the spectrum and frequency of different chlorophyll mutations was recorded among the different treatments (Table 1). The highest frequency of chlorophyll mutations (9.74\%) was recorded in the $0.25 \%$ EMS treatment while lowest (1.14\%) was found in $0.2 \%$ SA treatment.

Spectrum of chlorophyll mutations in $\mathrm{M}_{1}$ generation (Table 1) indicates presence of broad chlorophyll mutant spectrum, comprising 11 types. Out of the 11 different types of mutations maximum (10) was induced by $10 \mathrm{kR}$ gamma rays treatment followed by $5 \mathrm{kR}$ and $0.25 \%$ EMS treatments which induced 9 types of chlorophyll mutants. Highest frequency of viridis (2.56\%) and chlorina mutant (1.53\%) was recorded in 0.25\% EMS treatment. The highest frequency of yellow viridis mutant (1.16\%) was found with $0.05 \%$ EMS treatment. Xantha (1.56\%) and

Table 1. Frequency and spectrum of chlorophyll mutants in $\mathrm{M}_{1}$ generation of D. malabaricum

\begin{tabular}{|c|c|c|c|c|c|c|c|c|c|c|c|c|c|c|}
\hline \multirow[t]{2}{*}{ Treatment } & \multirow{2}{*}{$\begin{array}{l}\text { No.of } \\
\text { Seeds } \\
\text { sown }\end{array}$} & \multirow{2}{*}{$\begin{array}{c}\text { No. of } \\
\text { M }_{1} \text { plant } \\
\text { progenies }\end{array}$} & \multicolumn{11}{|c|}{ Relative frequency (\%) of chlorophyll spectrum } & \multirow{2}{*}{$\begin{array}{c}\text { Total } \\
\text { Frequency } \\
(\%)\end{array}$} \\
\hline & & & Albina & $\begin{array}{c}\text { Albina } \\
\text { green }\end{array}$ & Xantha & Aurea & Chlorina & Viridis & $\begin{array}{l}\text { Yellow } \\
\text { viridis }\end{array}$ & Tigrina & Striata & Maculata & Variegated & \\
\hline$\overline{\text { Control }}$ & 300 & 231 & 0.00 & 0.00 & 0.00 & 0.00 & 0.00 & 0.00 & 0.00 & 0.00 & 0.00 & 0.00 & 0.00 & 0.00 \\
\hline $0.01 \%$ EMS & 300 & 216 & 0.00 & 0.00 & 0.46 & 0.00 & 0.00 & 0.46 & 0.00 & 0.92 & 0.46 & 0.46 & 0.00 & 2.76 \\
\hline 0.05\% EMS & 300 & 171 & 0.58 & 0.00 & 0.58 & 0.00 & 0.58 & 1.75 & 1.16 & 0.58 & 1.16 & 0.58 & 0.58 & 7.60 \\
\hline 0.10\% EMS & 300 & 219 & 0.45 & 0.91 & 0.91 & 0.00 & 0.00 & 0.91 & 0.45 & 0.00 & 0.45 & 0.00 & 0.00 & 4.08 \\
\hline 0.15\% EMS & 300 & 231 & 0.00 & 0.43 & 0.43 & 0.00 & 0.00 & 0.43 & 0.00 & 0.43 & 0.43 & 0.00 & 0.00 & 2.15 \\
\hline $0.20 \%$ EMS & 300 & 186 & 0.00 & 0.53 & 0.00 & 0.00 & 0.00 & 0.53 & 0.53 & 0.00 & 1.07 & 0.00 & 0.00 & 2.68 \\
\hline 0.25\% EMS & 300 & 195 & 0.51 & 1.02 & 0.51 & 0.51 & 1.53 & 2.56 & 1.02 & 0.00 & 1.53 & 0.00 & 0.51 & 9.74 \\
\hline 0.30\% EMS & 300 & 162 & 0.61 & 0.00 & 1.23 & 0.61 & 0.61 & 1.23 & 0.00 & 0.00 & 0.00 & 0.00 & 0.00 & 4.29 \\
\hline $0.01 \%$ SA & 300 & 210 & 0.47 & 0.00 & 0.47 & 0.00 & 0.47 & 0.47 & 0.00 & 0.00 & 0.00 & 0.47 & 0.47 & 2.85 \\
\hline $0.05 \%$ SA & 300 & 180 & 0.55 & 0.00 & 1.11 & 0.00 & 0.00 & 1.11 & 0.00 & 0.00 & 0.00 & 0.55 & 1.11 & 4.44 \\
\hline $0.10 \%$ SA & 300 & 192 & 0.52 & 0.00 & 1.56 & 1.04 & 1.04 & 0.52 & 0.00 & 0.00 & 0.52 & 1.04 & 0.52 & 6.77 \\
\hline $0.15 \%$ SA & 300 & 216 & 0.46 & 0.00 & 0.46 & 0.46 & 0.46 & 0.92 & 0.00 & 0.00 & 0.46 & 0.00 & 0.00 & 3.24 \\
\hline $0.20 \% \mathrm{SA}$ & 300 & 174 & 0.00 & 0.00 & 0.00 & 0.57 & 0.00 & 0.57 & 0.00 & 0.00 & 0.00 & 0.00 & 0.00 & 1.14 \\
\hline $0.25 \%$ SA & 300 & 165 & 0.60 & 0.00 & 0.60 & 0.60 & 0.60 & 1.21 & 0.00 & 0.00 & 0.00 & 0.60 & 0.00 & 4.24 \\
\hline $0.30 \%$ SA & 300 & 168 & 0.59 & 0.59 & 0.00 & 0.00 & 0.00 & 1.19 & 0.00 & 0.00 & 0.00 & 0.00 & 0.00 & 2.37 \\
\hline \multicolumn{15}{|l|}{ Gamma rays } \\
\hline $5 \mathrm{kR}$ & 300 & 225 & 0.44 & 0.00 & 0.44 & 0.00 & 0.88 & 0.44 & 0.00 & 0.44 & 0.44 & 0.00 & 0.44 & 3.52 \\
\hline $10 \mathrm{kR}$ & 300 & 228 & 0.43 & 0.43 & 0.87 & 0.43 & 0.43 & 0.87 & 0.43 & 0.43 & 0.87 & 0.00 & 0.87 & 6.06 \\
\hline $15 \mathrm{kR}$ & 300 & 189 & 0.00 & 1.05 & 1.05 & 0.52 & 0.00 & 2.64 & 0.00 & 0.00 & 2.11 & 0.00 & 0.52 & 7.93 \\
\hline $20 \mathrm{kR}$ & 300 & 183 & 0.00 & 0.00 & 0.54 & 0.00 & 0.00 & 1.09 & 0.54 & 0.00 & 0.54 & 1.09 & 0.54 & 4.34 \\
\hline $25 \mathrm{kR}$ & 300 & 150 & 0.00 & 0.00 & 0.66 & 0.00 & 0.00 & 0.66 & 0.00 & 0.00 & 0.66 & 0.00 & 0.00 & 1.98 \\
\hline
\end{tabular}



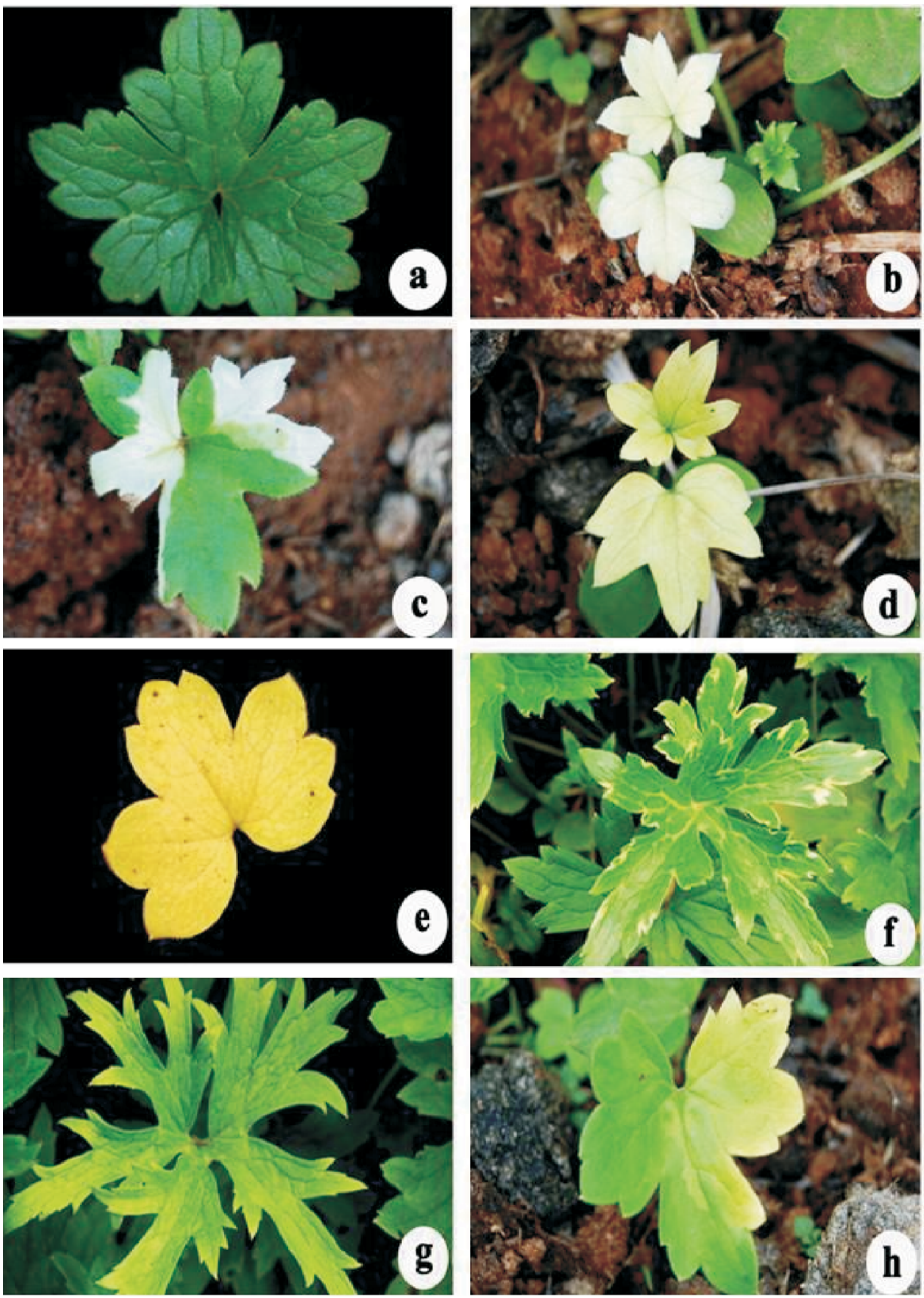

Fig. 1. Chlorophyll mutants in D. malabaricum (Huth) Munz. a: Control, b: Albina, c: Albina green, d: Xantha, e: Aurea, f: Chlorina, g: Viridis, h: Yellow viridis 

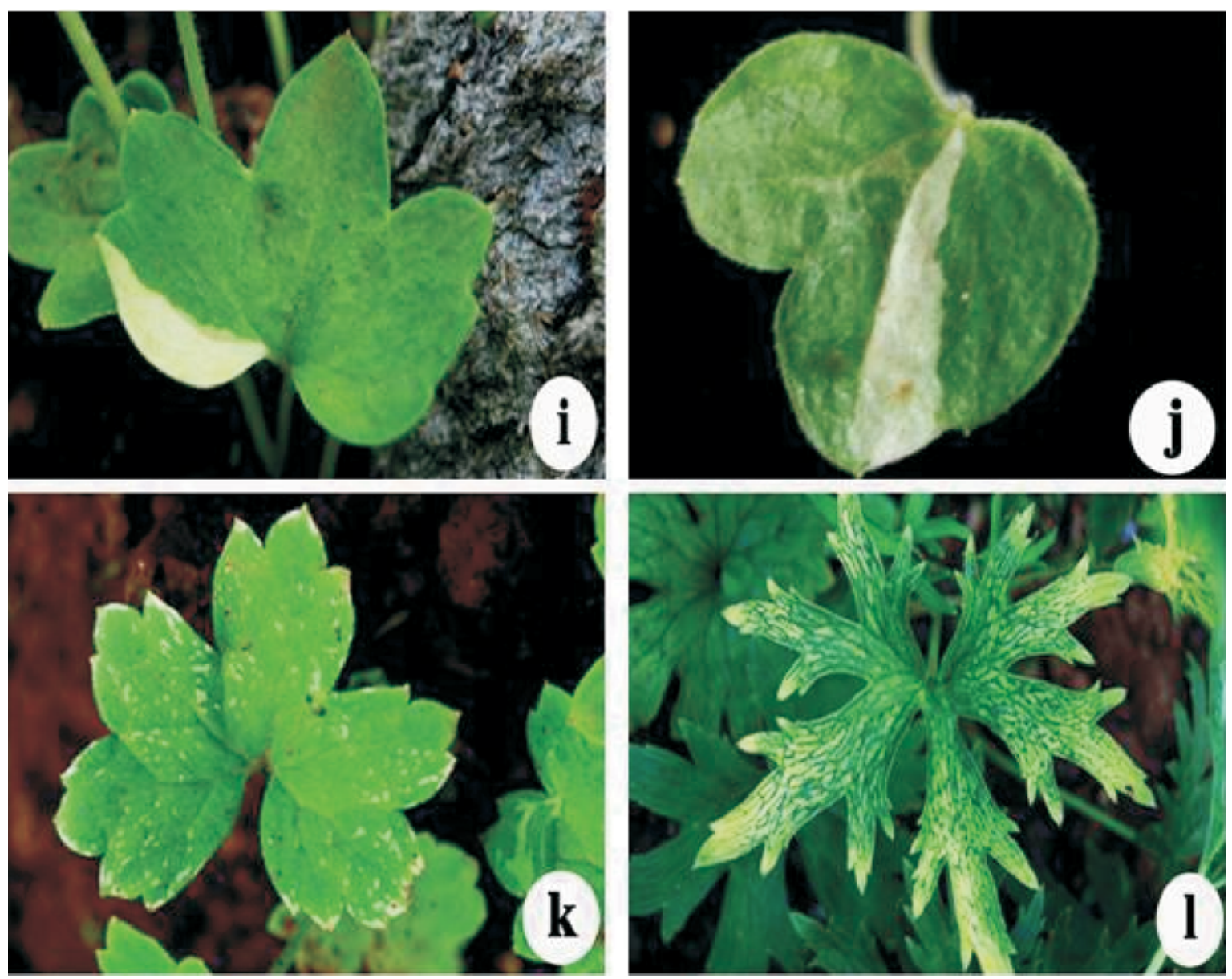

Fig. 2. Chlorophyll mutants in D. malabaricum (Huth) Munz. i: Tigrina, j: Striata, k: Maculata, l: Variegated

aurea (1.04\%) mutants recorded highest frequency in $0.10 \% \mathrm{SA}$ treatment. Highest frequency of tigrina mutants was found with $0.01 \%$ EMS and striata in case of $15 \mathrm{kR}$ gamma rays treatment (2.11\%). The higher frequency of albina green was observed in the treatment $0.10 \%$ EMS (0.91\%), while albina mutants were found in $0.30 \%$ EMS (0.61\%), maculata mutants in $20 \mathrm{kR}$ gamma rays treatment (1.09\%) while variegated type mutant was found under $0.05 \%$ SA treatment. Among the mutagens applied mutation frequency in EMS was higher than sodium azide and gamma ray treatments. Thus EMS proved to be the most efficient mutagen in all the mutagens tested followed by gamma rays and SA. Among the mutants recorded, viridis type was more predominant

Table 2. Chlorophyll content in normal type and chlorophyll deficient mutants of D. malabaricum

\begin{tabular}{lcccc}
\hline Phenotypes & $\begin{array}{c}\text { Chlorophyll } \\
a\left(\mathrm{mg} \mathrm{g}^{-1} \text { of }\right. \\
\text { fresh tissue) }\end{array}$ & $\begin{array}{c}\text { Chlorophyll } \\
b\left(\mathrm{mg} \mathrm{g}^{-1} \text { of }\right. \\
\text { fresh tissue })\end{array}$ & $\begin{array}{c}\text { Total } \\
\text { Chlorophyll } \\
\left(\mathrm{mg} \mathrm{g}^{-1} \text { of }\right. \\
\text { fresh tissue })\end{array}$ & $\begin{array}{c}\text { Chlorophyll } \\
a / b \text { ratio }\end{array}$ \\
\hline Normal & 1.05 & 0.33 & 1.38 & 3.18 \\
Chlorina & 0.88 & 0.35 & 1.23 & 2.51 \\
Maculata & 0.74 & 0.24 & 0.98 & 3.08 \\
Variegated & 0.60 & 0.18 & 0.78 & 3.33 \\
Striata & 0.53 & 0.18 & 0.71 & 2.94 \\
Tigrina & 0.49 & 0.19 & 0.68 & 2.57 \\
Viridis & 0.44 & 0.20 & 0.64 & 2.20 \\
Yellow viridis & 0.28 & 0.16 & 0.44 & 1.75 \\
Albina green & 0.26 & 0.15 & 0.41 & 1.73 \\
Aurea & 0.16 & 0.11 & 0.27 & 1.45 \\
Xantha & 0.08 & 0.11 & 0.19 & 0.72 \\
Albina & 0.00 & 0.00 & 0.00 & 0.00 \\
\hline
\end{tabular}

followed by xantha and striata. Viridis type was present in all the doses of the mutagens and reported maximum frequency in all the mutagenic treatments, whereas maculata type of mutant was rarely induced in EMS and SA treatment and its frequency was also less. Albina and ablina green types of mutants were observed with low frequency in gamma rays. All the type of chlorophyll mutants were found in all the treatments of EMS, SA and gamma rays. However, yellow viridis and tigrina type were completely absent in SA treated populations.

Chlorophyll content in chlorophyll deficient mutants: The intensity of green colouration in the leaves differed among the different types of chlorophyll deficient mutants, ranging from chlorina to xantha type of mutants. The chlorophyll content (Table 2) of various mutants and normal leaf tissues generally reflected the differences in colour that were apparent to the eye. In all tissues examined, the mutants contained significantly less chlorophyll than normal plants. Among the mutants, xantha $\left(0.19 \mathrm{mg} \mathrm{g}^{-1}\right)$ and aurea $\left(0.27 \mathrm{mg} \mathrm{g}^{-1}\right)$ contained the least chlorophyll and those of chlorina $\left(1.23 \mathrm{mg} \mathrm{g}^{-1}\right)$ the most. The other chlorophyll mutants maculata $\left(0.98 \mathrm{mg} \mathrm{g}^{-1}\right)$, variegated $\left(0.78 \mathrm{mg} \mathrm{g}^{-1}\right)$, striata $\left(0.71 \mathrm{mg} \mathrm{g}^{-1}\right)$, tigrina $\left(0.68 \mathrm{mg} \mathrm{g}^{-1}\right)$, viridis $\left(0.64 \mathrm{mg} \mathrm{g}^{-1}\right)$, yellow viridis $\left(0.44 \mathrm{mg} \mathrm{g}^{-1}\right)$, and albina green $\left(0.41 \mathrm{mg} \mathrm{g} \mathrm{g}^{-1}\right)$ contained significantly less chlorophyll than those of chlorina. Albina type was totally devoid of chlorophyll. Since the plants with albina mutations were unable to carry on photosynthesis, they died in the seedling stage after having exhausted the food available in the endosperm (Drew Schwartz, 1949). 
However, the chlorophyll $a / b$ ratios for various leaf tissues differed significantly among mutant and normal plants (Table 2). In variegated type (3.33) of mutant, the ratio was considerably higher in leaf tissues compared to normal (3.18), indicating a low level of chlorophyll $b$. Ratios for maculata (3.08) leaves were nearly normal and the other type of chlorophyll deficient mutants showed $a / b$ ratio significantly less than the normal.

\section{Discussion}

Frequency and spectrum of chlorophyll mutants: Chlorophyll development seems to be controlled by many genes located on several chromosomes which could be adjacent to centromere and proximal segment of chromosome (Swaminathan, 1964; Goud 1967). Mutations in these chlorophyll genes are reflected in the $M_{1}$ and subsequent generations in the form of different types of mutants. In the present study, eleven different types of mutants were recorded in the segregating $\mathrm{M}_{1}$ plants.

Among all the mutagens tested EMS induced maximum frequency of chlorophyll mutations indicating their greater effectiveness. Whereas gamma rays were proved to be more effective than SA. The comparative superiority of chemical mutagen EMS over gamma rays and SA producing a higher frequency and spectrum of chlorophyll mutations suggest that the chemical mutagen EMS is more efficient in inducing mutations of genes needed for chlorophyll development (Shah et al., 2006). Higher frequency and a wider spectrum of chlorophyll mutants in chemical mutagen EMS have been reported by Bhattacharya (2003), Sharma and Sharma (1984), Marki and Bianu (1970), Kawai and Sato (1969) in carnation, lentil, flax and rice, respectively. In the present investigation no dose dependent increase in the frequency and spectrum of chlorophyll mutations was observed, the lower and higher doses of mutagens produced higher frequency of chlorophyll mutations in EMS and SA. For gamma irradiation higher frequency of chlorophyll mutation with moderate doses of mutagens was observed. It seems that the strong mutagens reach their saturation point even at lower or moderate doses in the highly mutable genotypes and further increase in dose does not add to the mutation frequency. With increase in dose beyond a point, the strong mutagens become more toxic than the higher doses of relatively weaker mutagens. The present findings of differential effect of physical and chemical mutagens in inducing chlorophyll mutations are in agreement with earlier reports (Gustafson, 1947; Sreekantaradhya and Madhavamenon, 1979).

Different pattern of chlorophyll mutations were reported by Haq (1990) who observed maximum number of xantha mutants in three kabuli chickpea genotypes, similar results were observed by Lal et al.(2009) in Black gram and in Chickpea by Khan et al.(2005). But our results are contrary to the findings of these. They reported that the xantha mutants were predominant. But in the present studies, predominant occurrence of viridis mutant was observed. The reason for the appearance of greater number of viridis may be attributed to involvement of polygenes in the chlorophyll formation (Gaul, 1964). Ambarkar (2005) reported predominance of viridis among chlorophyll mutant types in chickpea. Sjodin (1962) reported that viridis was most common in Vicia faba and xantha was the next most common mutant type, whereas albina was very rare mutant as in most leguminosae. The viridis types were predominant than albina, xantha and chlorina types, irrespective of the cultivar in rice bean as reported by Prakash and Shambulingappa (1999), Prakash and Khanure (2000). Higher efficiency of EMS in inducing chlorophyll mutations and highest frequency of viridis mutant was observed by Charry and Bhalla (1988) in piegeonpea and by Khan and Tyagi (2009) in Soybean. Further isolation and characterization of chlorophyll genome of mutant may be helpful in understanding the nature of mutation at molecular level.

Chlorophyll content in chlorophyll deficient mutants: The photosynthetic pigments are bound to specialized pigment binding proteins with different functions. Mutants with altered pigment composition represent a useful model for studying the influence of these changes on the structure and function of the thylakoid membranes. The mutants show relatively low chlorophyll content than that of normal. The average Chl $a$, Chl $b$, and TChl of mutant types was significantly less than those of the normal leaf. There were some mutant plants showing higher $\mathrm{Chl} a / b$ ratio than the normal ones, as observed in the variegated type. This revealed that rate of change in the content of Chl $a$ and Chl $b$ was not the same among the mutants, possibly was due to the impair of Chl $b$ synthesis during chloroplast development. Increase in Chl $a / b$ ratio in mutant plants were reported earlier by Darr and Arntzen (1986), Picaud and Dubertret (1986) and Tanaka et al. (1993). Chlorophyll synthesis in the mutant seemed to be environmentally dependent, especially on light intensity during the growing period. This chlorophyll deficiency reduced the rate of plant growth. Plants with a higher (Niels et al., 1978) or a lower (Vaughn et al., 1978; Kirchoff et al., 1989) Chl a/b ratio than that of their respective normal plants have been reported to be able to survive photoautotrophically. The more important determinant in photoautotrophism may be the absolute amount of the total Chl $a$ and Chl $b$ possessed by a plant. The present results supports the claim that the number of induced chlorophyll mutations can serve as a reliable indicator of the mutability of plant species and varieties (Gaul, 1964; Monti, 1968 and Mamalyga et al., 1974).

The study of induced genetic variability and frequency and spectrum of chlorophyll mutations in D. malabaricum is first report in D. malabaricum and confirmed the findings of Kaul and Bhan (1977) that genetic differences even of a single gene, induce significant changes in mutagen sensitivity that influence not only the rate but also the spectrum of recoverable mutations. It is further suggested that as all the EMS, SA and gamma radiation doses induced reasonable chlorophyll mutations, hence all these treatments could be used in mutation breeding programs for inducing viable mutations. The chlorophylls were eliminated as the cause of the lethality in many chlorophyll deficient mutants, since both chlorophylls a and b, as determined by spectroscopic analysis, were found to be abundant in the lethal as well as in the viable mutants.

It is therefore concluded that although the chlorophyll mutations do not have any economic value due to their lethal nature, such a study could be useful in identifying the threshold dose of a mutagen that would increase the genetic variability and number of economically useful mutants in the segregating generations. 


\section{Acknowledgements}

The authors wish to thank Dr. S.G. Bhagwat, Nuclear Agriculture and Biotechnology Division, BARC, Mumbai for irradiating the seeds used in the physical mutagenesis part of this research and $\mathrm{Mr}$. Sandeep R. Pai for help with the preparation of photo plates.

\section{References}

Alcantara, T.P., P.W. Bosland and D.W. Smith, 1996. EMS-induced seed mutagenesis of Capsicum annuum. J. Hered., 87(3): 239-241.

Ambarkar, A.S., P.N. Harer and R.V. Kulkarni, 2005. Radiosensitivity and visible mutations in chickpea [Cicer arietinum (L.)]. Advances in Plant Sciences, 18(2): 559-563.

Anon., 1995. In: Symposium and Proceedings of Induced Mutations and Molecular Techniques for Crop Improvement. IAEA and FAO, Vienna, Austria.

Arnon, D.I. 1949. Copper enzymes in isolated Chloroplasts. Polyphenoxidase in Beta vulgaris. Plant Physiol., 24: 1-15.

Aviv, D. and E. Galum, 1985. An in vitro procedure to assign pigment mutations in Nicotiana to either the chloroplast or the nucleus. $J$. Hered., 76, 135-136.

Bhattacharya, C. 2003. Effect of ethyl methanesulphonate on carnation (Dianthus caryophyllus L.). Environ. Ecol., 21(2): 301-305.

Blanché, C. 1991. Revisió biosistemàtica del gènere Delphinium L. al a Península Ibèrica i a les Illes Balears. Institut d'Estudis Catalans, Barcelona.

Blixt, S. 1961. Quantitative studies of induced mutations in peas. V. Chlorophyll mutations. Agr. Hort. Genet., 19: 1-402.

Blixt, S. 1972. Mutation in Pisum. Agr. Hort. Genet., 30: 1-293.

Bretagne-Sagnard, B., G. Fouilloux and Y. Chupeau, 1996. Induced albina mutations as a tool for genetic analysis and cell biology in flax (Linum usitatissimum). J. Exp. Bot., 47(295): 189-194.

Broertjes, C. and A.M. Van Harten, 1988. Applied Mutation Breeding for Vegetatively Propagated Crops. Elsevier, Amsterdam-Oxford-New York-Tokyo: 165-169.

Chary, N.S. and J.K. Bhalla, 1988. Mutagenic effectiveness and efficiency of gamma rays and EMS on pigeonpea (Cajanus cajana L.Millsp.). J. Cytol. \& Genet., 23: 190-193.

D’Amato, F., G.T. Scarascia, L.M. Monti and A. Bozzini, 1962. Types and frequencies of chlorophyll mutations in durum wheat induced by radiation and chemicals. Rad. Bot., 2: 217-239.

Darr, S.C. and C.J. Arntzen, 1986. Reconstitution of light harvesting chlorophyll $a / b$ pigment-protein complex into developing chloroplast membranes using a dialyzable detergent. Plant Physiol., 80: 931937.

Drew Schwartz, 1949. The chlorophyll mutants of Maize. Botanical Gazette Chicago Jour., 3(2): 123-130.

Gaul, H. 1964. Mutations in plant breeding. Rad. Bot., 4: 155-232.

Gichner and J. Veleminsky. 1965. Induction of chlorophyll chimeras by $\mathrm{X}$-rays and ethyl-methanesulphonate (EMS) in different heterozygous strains of Arabidopsis thaliana. Proc. Symp. "Induction of Mutations and the Mutation Process” Praha, 27-29. Sept. 1963, pp 54-56.

Goud, J.V. 1967. Induced polygenic mutation in hexaploid wheats. Rad. Bot., 7: 321-331.

Gustafson, A. 1940. The mutation system of the chlorophyll apparatus, Lunda Guv. Asskr. M.F. Adv., 2(11): 1-40.

Gustafsson, A. 1951. Induction of changes in genes and chromosomes II Mutations, environment and evolution Cold Spring. Harbour Symp Quant Biol., 16: 263-281.

Gustafsson, A. 1947. Mutations in agricultural plants. Hereditas, 24: 3-93.

Haq, M.A. 1990. Genetic and physiologic studies on induced mutants of chickpea (Cicer arietinum L.). Ph.D. Thesis, University of Punjab Lahore., Pakistan.
Kaul, M.L.H. and A.K. Bhan, 1977. Mutagenic effectiveness and efficiency of EMS, DES and gamma rays in rice. Theoret. Appl. Genet., 50: 241-246.

Kawai, T. and H. Sato, 1969. Studies on early heading mutations in rice. Bull. Nat. Inst. Agric. Sci., (Japan), Series D., 20: 1-33.

Khalatkar, A.S. and Y.R. Bhargava, 1982. 2, 4-dichlorophenoxy acetic acid - a new environmental mutagen. Mut. Res., 103: 111-114.

Khan, M.H. and S.D. Tyagi, 2009. Studies on chlorophyll mutations in Soybean, Glycine max (L.) Merrill. Front. Agric. China, 3(3): 253-258.

Khan, S., Mohd. Rafiq Wani, Mehraj-ud-din Bhat and Kouser Parveen, 2005. Induced chlorophyll mutations in chickpea (Cicer arietinum L.). Int. J. Agr. Biol., 7 (5): 764-767.

Kharkwal, M.C. 1998. Induced mutations in chickpea (Cicer arietinum L.) II. Frequency and spectrum of chlorophyll mutations. Ind. J. Genet., 58: 465-474.

Kirchhoff, W.R., A.E. Hall and W.W. Thomson, 1989. Gas exchange, carbon isotope discrimination and chloroplast ultrastructure of a chlorophyll-deficient mutant of cowpea. Crop Sci., 29: 109-115.

Lal G.M., Bini Toms and Sapna Smith, 2009. Induced chlorophyll mutations in black gram. Asian J. Agr. Sci., 1(1): 1-3.

Levine, R.P. 1972. Interactions between nuclear and organelle genetic systems. In: Evolution of Genetic systems. Brook Haven Symp Biol., 23: 503-533.

Mamalyga, V.S., M.I. Kulik and V.F. Logvinenko, 1974. Induced chlorophyll mutations in hard spring wheat. Dokl. Akad. Nauk SSSR., 215: 211-213.

Marki, A. and M. Bianu,1970. Gamma rays and EMS induced mutaions in flax. Genetika, 6: 24-28.

Miller, P.D., K.C. Vaughn and K.G. Wilson, 1984. EMS-induced chloroplast mutagenesis in crops. J. Hered., 75: 86-92.

Mitra, P.K. and G. Bhowmik,1999. Studies on the frequency and segregation of induced chlorophyll mutations in Nigella sativa L. Adv. Plant Sci., 12: 125-129.

Monti, L.M. 1968. Mutation in peas induced by diethyl sulphate and X-rays. Mutat. Res., 5: 187-191.

Niels, N.C., R.M. Smillie, K.W. Henningsen, D. Wettstein and C.S. von French, 1978. Composition and function of thylakoid membranes from grana-rich and grana-deficient chloroplast mutants of barley. Plant Physiol., 63: 174-182.

Pai, S.R., M.Y. Kamble, S.R. Yadav, G.B. Dixit, N.V. Pawar, P.D. Chavan and U.S. Yadav, 2007. Karyomorphological analysis of $D$. malabaricum (Huth Munz: A rare endemic potential ornamental plant from peninsular India. Cytologia, 72(3): 319-322.

Picaud, A. and G. Dubertret, 1986. Pigment protein complexes and functional properties of tetratype resulting from crosses between CP1 and CP2 less Chlamydomonas mutants. Photosyn. Res., 7: 221-236.

Prakash, B.G. and K.G. Shambulingappa, 1999. Estimation of chlorophyll and viable mutation under $\mathrm{M}_{2}$ generatpion in rice bean (Vigna umbellate L. Thumb). Karnataka J. Agr. Sci., 12(1-4): 58.

Prakash, B.G. and S.K. Khanure, 2000. Isolation of mutants and their frequencies under $\mathrm{M}_{2}$ generation in rice bean (Vigna umbellata $\mathrm{L}$. Thumb). Madras Agri. J., 86(10/12): 568-572.

Prasad, A.B. and A.K. Das, 1980. Studies on induced chlorophyll mutations in Lathyrus sativus L. Cytologia, 45: 335-341.

Rau, M.A. 1993. Ranunculaceae. In: Flora of India (Sharma, B. D., Balkrishnan N.P., Rao, R.R., and Hajara, P.K. eds.). Botanical survey of India, Calcutta. I: pp. 1-145.

Reddy, V.R.K. and P.K. Gupta, 1989. Induced mutations in Triticale. Frequency and spectrum of chlorophyll mutations. Indian J. Genet., 49: 183-190.

Shah Tariq Mahmud, Javed Iqbal Mirza, Muhammed Ahsanul Haq and Babar Manzoor Atta, 2006. Induced genetic variability in chickpea (Cicer arietinum L.) I. Frequency and spectrum of chlorophyll mutations. Pak. J. Bot., 38(4): 1217-1226. 
Sharma, S.K. and B. Sharma, 1981. Induced chlorophyll mutation in Lentil. Indian J. Genet., 41: 328-333.

Sharma, S.K. and B. Sharma, 1984. Pattern of induced macro and micro mutations with gamma rays in lentil. Environ. Exp. Bot., 24: 343-351.

Sjodin, J. 1962. Some observations in X1 and X2 of Vicia faba L. after treatment with different mutagens. Hereditas, 48: 565-586.

Solanki, I.S. 2005. Isolation of macromutations and mutagenic effectiveness and efficiency in lentil (Lens culinaris Medik.). Indian J. Genet., 65: 264-268.

Sreekantaradhya, R. and P.M. Madhavamenon, 1979. Induced mutagenesis in finger millet with gamma rays and ethymethane sulphonate. II. Chlorophyll mutation frequency and spectrum. Environ. Exp. Bot., 19: 123-126.

Swaminathan, M.S. 1964. A comparison of mutation induction in diploids and polyploids. In: The use of induced mutations in plant breeding. Rad. Mut. Organ., FAO/IAEA Vienna, 619-641.

Swaminathan, M.S., V. L. Chopra and S. Bhaskaran, 1962. Chromosome aberrations frequency and spectrum of mutations induced by EMS in barley. Ind. J. Genet., 22: 192-207.
Tanaka, Y., A. Tanaka and H. Tsuji, 1993. Effects of 5- aminolevulinic acid on the accumulation of chlorophyll $b$ and apoproteins of the light-harvesting chlorophyll $a / b$-protein complex of photosystem II. Plant Cell Physiol., 34: 465-472.

Van den Bulk, R.W, H.J.M. Loffer, W.H. Lindhout and M. Koornneef, 1990. Somaclonal variation in tomato: effect of explant source and a comparison with chemical mutagenesis. Theor. Appl.Genet., 80: 817-825.

Vaughn, K.C., K.G. Wilson and K.D. Stewart, 1978. Light-harvesting pigment protein complex deficiency in Hosta (Liliaceae). Planta, 143: 275-278.

Walles, B. 1973. Plastid structures and mutations. In: Structure and Function of Chloroplasts, Gibba M (ed), Springer Verlag New York, pp. 51-58.

Wildman, S.G. 1973. An approach towards ascertaining the function of chloroplast DNA in tobacco plants. In: Autonomy of Bio-genesis, Linnae N K and Smillie A W (eds), New York AE Rube Co.

Received: June, 2010; Revised: December, 2010; Accepted: December, 2010 